\title{
Serendipity in Inborn Errors of Metabolism: Combining Two Genetic Mutations in a Single Patient
}

\author{
Khalil Charafeddine, Mohammad-Zouheir Habbal* \\ Department of Pathology and Laboratory Medicine, American University of Beirut Medical Center, Beirut, Lebanon
}

Article Info

\section{Article Notes}

Received: June 09, 2016

Accepted: July 08, 2016

\section{${ }^{*}$ Correspondence:}

Dr. Mohammad-Zouheir Habbal, Department of Pathology and Laboratory Medicine, American University of Beirut Medical

Center, B.O. Box: 11-0236

Beirut, Lebanon 1107-2020,

Telephone: 961-1-350000 Ext: 5220

Fax: 961-1-370845

E-mail: mh03@aub.edu.lb

( 2016 Mohammad-Zouheir Habbal. This article is distributed under the terms of the Creative Commons Attribution 4.0 International License.

\section{Keywords}

Inborn error of metabolism

Neonatal screening

Genetic mutation

Incidence

Prevalence
Inborn Errors of Metabolism (IEM) are rare disorders, with the majority having an incidence of less than 10 per 100,000 births, and a total incidence of all metabolic diseases reaching 40 per 100,000 births. The incidences of Amino Acid disorders excluding Phenylketonuria and Glycogen Storage disease are 7.6 and 2.3 per 100,000 live births respectively ${ }^{1}$. The incidence and the frequency of inborn error of metabolisms vary worldwide and are based on racial and ethnic structure of population. Specific genetic mutations can be more frequently seen in specific ethnicities. For instance, sickle cell anemia, caused by a genetic mutation in the HBB gene, is more common in people of African, African-American, and Mediterranean origins. Ashkenazi Jewish are also well known to host the mutation responsible for Tay-Sachs disease ${ }^{2}$. In other words, diseases tend to "cluster" in families because genes are passed down from ancestors to offspring. Therefore, variations in the incidence and prevalence of genetic mutations are quite different from one geographic area to another and can be partially attributed to the evolutionary factors that influence genetic variation in general.

Alkaptonuria is a rare autosomal recessive disease with an incidence of 1:250,000 - 1,000,000 (Table 1). The homogentisate 1,2-dioxygenase (HGD) gene codes for the enzyme necessary to break down the homogentisic acid into maleylacetoacetic acid. This HGD gene is expressed in many organs mainly the liver, kidney, prostate, osteoarticular joints, and the gastrointestinal tract. Alkaptonuria is caused by the accumulation of homogentisic acid (HGA) in the body, with some secreted in the urine. HGA undergoes oxidation and then polymerization in connective tissues, cardiovascular, and ocular tissues, causing a bluish discoloration, an entity named as Ochronosis. Moreover, individuals with Alkaptonuria might have dark urine that turns black when exposed to air, a pathognomonic sign of this disease. Features of Alkaptonuria include increased risk of developing aortic valve and coronary artery diseases, and osteoarthritis-like damage in joints and spine. Moreover, Alkaptonuria is also classified as a secondary amyloidosis because of the deposition of serum amyloid A related to HGA ochronotic pigments; the latter was proven to be co-localized with Alkaptonuria type II Amyloids in the tissues ${ }^{3,4}$

Pompe is a lysosomal storage disease type II. It is a rare autosomal recessive genetic disease caused by a mutation in the GAA gene responsible for the production of acid $\alpha$-glucosidase (also known as acid maltase) enzyme. This enzyme breaks down glycogen into 


\begin{tabular}{|c|c|c|c|c|c|c|c|c|}
\hline Case \# & Reference & Disease 1 & Disease 2 & $\begin{array}{c}\text { Incidence } \\
\text { for Disease } 1\end{array}$ & $\begin{array}{l}\text { Incidence for } \\
\text { Disease } 2\end{array}$ & $\begin{array}{l}\text { Mutation } \\
\text { type for } \\
\text { Disease } 1\end{array}$ & $\begin{array}{l}\text { Mutation } \\
\text { type for } \\
\text { Disease } 2\end{array}$ & Marriage Type \\
\hline 1 & 11 & PKU & Fabry Disease & $1: 15,000$ & $\begin{array}{c}1: 80,000- \\
117,000\end{array}$ & $\begin{array}{l}\text { Autosomal } \\
\text { Recessive }\end{array}$ & X-Linked & $\begin{array}{c}\text { Non- } \\
\text { Consanguineous }\end{array}$ \\
\hline 2 & 12 & $\begin{array}{l}\text { McArdle } \\
\text { Disease }\end{array}$ & MDS & $1: 100,000$ & Unknown & $\begin{array}{l}\text { Autosomal } \\
\text { Recessive }\end{array}$ & $\begin{array}{l}\text { Autosomal } \\
\text { Recessive }\end{array}$ & Consanguineous \\
\hline 3 & $13-15$ & $\begin{array}{l}\text { Tyrosinemia } \\
\text { Type } 1\end{array}$ & Angelman Syndrome & $1: 100,000$ & $1: 12,000-20,000$ & $\begin{array}{l}\text { Autosomal } \\
\text { Recessive }\end{array}$ & $\begin{array}{l}\text { Paternal } \\
\text { Uniparental } \\
\text { Isodisomy }\end{array}$ & $\begin{array}{c}\text { Non- } \\
\text { Consanguineous }\end{array}$ \\
\hline 4 & $3,4,16-18$ & Alkaptonuria & Huntington Disease & $\begin{array}{l}1: 250,000- \\
1,000,000\end{array}$ & $1: 30,000$ & $\begin{array}{l}\text { Autosomal } \\
\text { Recessive }\end{array}$ & $\begin{array}{l}\text { Autosomal } \\
\text { Dominant }\end{array}$ & Data not available \\
\hline 5 & $19-21$ & $\begin{array}{c}\text { Glutaric } \\
\text { Aciduria Type I }\end{array}$ & Isobutyrylglycinuria & $\begin{array}{c}1: 300- \\
100,000\end{array}$ & $\begin{array}{c}\text { Rare, with only } 5 \\
\text { cases reported }\end{array}$ & $\begin{array}{l}\text { Autosomal } \\
\text { Recessive }\end{array}$ & $\begin{array}{l}\text { Autosomal } \\
\text { Recessive }\end{array}$ & Consanguineous \\
\hline 6 & $3,4,16$ & Alkaptonuria & $\begin{array}{c}\text { Sucrase-Isomaltase } \\
\text { Deficiency }\end{array}$ & $\begin{array}{l}1: 250,000- \\
1,000,000\end{array}$ & $\begin{array}{c}\text { Unknown with } \\
1: 500-2,000 \text { in } \\
\text { Europe }\end{array}$ & $\begin{array}{l}\text { Autosomal } \\
\text { Recessive }\end{array}$ & $\begin{array}{l}\text { Autosomal } \\
\text { Recessive }\end{array}$ & Consanguineous \\
\hline 7 & $3,4,6,22,23$ & Alkaptonuria & Pompe Disease & $\begin{array}{l}1: 250,000- \\
1,000,000\end{array}$ & $1: 40,000$ & $\begin{array}{l}\text { Autosomal } \\
\text { Recessive }\end{array}$ & $\begin{array}{l}\text { Autosomal } \\
\text { Recessive }\end{array}$ & $\begin{array}{c}\text { Non- } \\
\text { Consanguineous }\end{array}$ \\
\hline
\end{tabular}

PKU: Phenylketonuria; MDS: Mitochondrial DNA Depletion Syndrome

Table 1: Cases of double Inborn Error of Metabolisms, their incidence, mutation and marriage types.

glucose in the lysozymes. Hence, deficiency in this enzyme leads to the deposition of glycogen in the body, mainly cardiac and skeletal muscles being the most severely affected. This will lead to massive vacuolar glycogen storage in almost all tissues. Three types of Pompe are present depending on the severity and the age at which the disease appears. These are known as classic infantileonset, non-classic infantile-onset, and late-onset. Severity can range from a mild slowly progressive muscle myopathy seen in adulthood period to a severe infantile-onset muscle hypotonia, weakness, and hypertrophic myopathy. So, patients experience myopathy, hypotonia, hepatomegaly, cardiomegaly, and failure to thrive. Pompe incidence is estimated to be 1:40,000 (Table 1) 5, $^{5,6}$.

The prevalence of IEMs in Lebanon is considered one of the highest in the region and even worldwide. Out of 49,750 newborns screened, 44 cases were detected to have genetic mutations. The total incidence in Lebanon is $1: 1130$ compared to $1: 1381$ in Saudi Arabia, 1:9300 in Japan, 1:2105 in Italy, 1:3315 in Germany, 1:3367 - 4310 in the United States ${ }^{7}$. The prevalence of Amino Acids disorders $(70.4 \%)$ is the highest among other inborn errors of metabolisms namely Organic Acids disorders and Fatty Acid Oxidation defects $(26.9 \%$ and $0.0 \%$ respectively). No statistical data are available regarding other inborn errors mainly Glycogen Storage disease ${ }^{7}$. Alkaptonuria and Pompe diseases are likely to occur in our geographic area (Middle East). Hence, having a single mutation in a patient is common as previously described hundreds of times in the literature. However, having more than one mutation in the same patient is an extremely rare occurrence. Human data presented in Table 1 were selected after an extensive search through PubMed and Medline. Different words were used to search for cases having combined genetic mutations in the literature, specifically in the inborn error of metabolism. "OR" and/or "AND" operators were used during the search. Only seven cases were found, including our case. Full data regarding case \#4 is not available. Three out of six cases (50\%) have parents with consanguineous type of marriage. Based on the incidence of Pompe disease and Alkaptonuria as depicted in Table 1, the incidence to have both Pompe disease and Alkaptonuria at the same time is approximately $1: 10,000,000,000-40,000,000,000$. Our case is the only one reported in the literature up to our knowledge. This is a very unusual finding to have such combination of two recessive mutations.

One of the main causes of the high incidence of IEM in the Middle East is the high rates of consanguinity. In the Arab world, consanguinity includes first cousins, double first cousins, and second cousins. Consanguinity also includes individuals with at least one common ancestor as seen in tribes, endogenous marriages, and intra-communities. The main cause of high consanguinity in the Arab region is due to socio-cultural factors such as preservation of family structure and properties, ease of marriage, and better relations with in-laws. The overall consanguinity ranges from $12.8 \%$ to $80.4 \%$. Consanguinity rate in the Lebanese population is considered low with respect to other Arab countries $(12.8 \%-42 \%)$. This rate can be as high as $80.4 \%$ as noted in Nubia in Egypt $^{8}$. IEMs are relatively common in our region. This is mainly due to the high rates of consanguinity as stated above. The total consanguinity can reach up to $67 \%$, reaching $49 \%$ with first cousin consanguinity ${ }^{7}$. Our case has no family history of parental consanguinity. Both his parents and his sister are clinically well. One of his cousins reported to have episodes of dark urine but was not reachable. Another one died at age of 14 years after having pneumonia and hepatosplenomegaly. 
Having parents not consanguineous makes the probability of finding a similar case even rarer.

Metabolic disorders can have early or late onset of signs and symptoms due to the deficiency or accumulation of biological products. The best clinical outcome of IEM patients is to have a prompt evaluation or screening and then referral for evaluation and management. Any delay in treatment can have drastic consequences and might cause death. Although neonatal screening programs have some false positivity and negativity mainly due to early screening, interference with drugs, etc.; however, it is a simple and reliable test available for screening newborns. Moreover, some diseases do not have a screening method during the neonatal period. Recently, the Pompe Disease Diagnostic Working Group reported the use of dried blood spot (DBS) as a minimally invasive, easy to collect and

\begin{tabular}{|c|c|c|c|c|c|c|c|c|}
\hline Case \# & Reference & $\begin{array}{l}\text { Age, } \\
\text { Gender }\end{array}$ & Signs \& Symptoms & PMH & Laboratory Results & Additional Testing & Molecular & Treatment \\
\hline 1 & 11 & $\begin{array}{c}3 \text { years, } \\
\text { Male }\end{array}$ & $\begin{array}{c}\text { Slow growth, } \\
\text { lack of appetite, } \\
\text { severe abdominal } \\
\text { pain, episodes of } \\
\text { gastroenteritis }\end{array}$ & - & BH4: normal level & $\begin{array}{l}\text { Plasma Galactosidase A: } \\
0.32 \mathrm{nmol} / \mathrm{h} / \mathrm{mL} \text {, Leukocyte } \\
\text { Galactosidase A: } 0.65 \\
\text { nmol } / \mathrm{h} / \mathrm{mg} \cdot \text { prot }^{\ddagger}\end{array}$ & \begin{tabular}{|c|} 
GLA sequencing: \\
hemizygous missense \\
mutation g.5234G>A \\
2 in the exon 2
\end{tabular} & $\begin{array}{l}\text { Diet therapy } \\
\text { for PKU }\end{array}$ \\
\hline 2 & 12 & $\begin{array}{l}\text { At birth, } \\
\text { Female }\end{array}$ & $\begin{array}{l}\text { Hepatomegaly, } \\
\text { jaundice, ascites, } \\
\text { liver failure }\end{array}$ & $\begin{array}{l}\text { Severe } \\
\text { hypotonia, } \\
\text { and thin } \\
\text { muscles, at } \\
\text { birth }\end{array}$ & $\begin{array}{c}\text { Hypoglycemia, } \\
\text { hyperlactacidemia } \\
(89 \mathrm{mg} / \mathrm{dL}, \mathrm{N}<20 \\
\mathrm{mg} / \mathrm{dL}) \text {, increased } \\
\text { creatine kinase }\end{array}$ & $\begin{array}{c}\text { Southern Blot: } 90 \% \\
\text { depletion of mtDNA, } \\
\text { phosphorylase activity } \\
\text { undetectable with MRCE } \\
\text { activity normal in muscle, } \\
\text { MRCE activity decreased } \\
\text { in Liver }\end{array}$ & $\begin{array}{l}\text { PYGM sequencing: } \\
\text { homozygous A1366G } \\
\text { in exon 11, dGK gene: } \\
\text { homozygous 4-base } \\
\text { pair GATT duplication } \\
\text { in exon } 6\end{array}$ & $\begin{array}{c}\text { Died at } 5 \\
\text { months of age }\end{array}$ \\
\hline 3 & $13-15$ & $\begin{array}{c}4 \\
\text { months, } \\
\text { Male }\end{array}$ & $\begin{array}{l}\text { Bronchiolitis, } \\
\text { liver failure, } \\
\text { decreased level } \\
\text { of consciousness, } \\
\text { psychomotor } \\
\text { retardation, } \\
\text { bouts of laughter, } \\
\text { absence of speech, } \\
\text { upper limb tremor }\end{array}$ & - & \begin{tabular}{|} 
Tyrosine: 499 umol/L \\
( $\mathrm{N}: 19-199)$, urine \\
succinylacetone: \\
$658 \mathrm{mOsm} / \mathrm{mol}$ \\
of creatinine (N: \\
undetectable), \\
plasma \\
succinylacetone: \\
29 umOsm/L, \\
afetoprotein: \\
$175,000 \mathrm{ng} / \mathrm{mL}$
\end{tabular} & $\begin{array}{l}\text { Karyotype and Fragile X } \\
\text { studies normal, } 15 q 12 \\
\text { methylation test: presence } \\
\text { of unmethylated paternal } \\
\text { \& loss of methylated } \\
\text { maternal alleles }\end{array}$ & $\begin{array}{c}\text { FAH gene: } \\
\text { homozygous with } \\
\text { IVS12+5G>A }\end{array}$ & $\begin{array}{l}\text { Tyrosine and } \\
\text { phenylalanine } \\
\text { restricted diet, } \\
\text { NTBC }\end{array}$ \\
\hline 4 & - & NA & NA & NA & NA & NA & NA & NA \\
\hline 5 & $19-21$ & $\begin{array}{l}3 \text { days, } \\
\text { Female }\end{array}$ & $\begin{array}{c}\text { Detected } \\
\text { by neonatal } \\
\text { screening at birth, } \\
\text { pyelonephritis \& } \\
\text { respiratory tract } \\
\text { infection at } 8 \text { \& } 11 \\
\text { months, enlarged } \\
\text { subarachnoid } \\
\text { space, cerebral } \\
\text { ventricles, } \\
\& \text { retarded } \\
\text { myelination }\end{array}$ & - & - & $\begin{array}{c}\text { Dried blood newborn } \\
\text { screening: glutarylcarnitine } \\
\text { (acylcarnitine C5DC):1.03 } \\
\text { umol/L (N: 0-0.017), C4 } \\
\text { acylcarnitine: } 1.23 \text { umol/L } \\
\text { (N: } 0-1.11 \text { ) }\end{array}$ & \begin{tabular}{|} 
GCDH sequencing: \\
homozygous missence \\
mutation c.482G.A \\
in exon 5. ACAD8 \\
sequencing: splice-site \\
mutation c. $841+3 G . C$ \\
in exon 7
\end{tabular} & $\begin{array}{l}\text { Dietary treat- } \\
\text { ment, supple- } \\
\text { mentation of } \\
\text { L-carnitine, } \\
\text { early inter- } \\
\text { ventions for } \\
\text { intercurrent } \\
\text { illnesses }\end{array}$ \\
\hline 6 & - & NA & NA & NA & NA & NA & NA & NA \\
\hline 7 & $3,4,6,22,23$ & $\begin{array}{c}6 \text { years, } \\
\text { Male }\end{array}$ & $\begin{array}{l}\text { Progressive motor } \\
\text { weakness \& } \\
\text { failure to thrive, } \\
\text { hepatomegaly, } \\
\text { black spot in the } \\
\text { right eye }\end{array}$ & $\begin{array}{l}\text { Recurrent } \\
\text { respiratory } \\
\text { infection, } \\
\text { greenish } \\
\text { mucoid stool, } \\
\text { dark urine, GE } \\
\text { reflux }\end{array}$ & $\begin{array}{c}\text { CPK: } 1679 \mathrm{IU} / \mathrm{L} \text {, } \\
\alpha \text {-Glucosidase: } 4.0 \\
\mathrm{~nm} / \mathrm{mg}^{*}, \text { Urine } \\
\text { homogentisic acid: } \\
15027 \mathrm{mmol} / \mathrm{mol} \\
\text { Creatine }\end{array}$ & $\begin{array}{l}\text { Urine } 1,4 \alpha \text {-Glucosidase } \\
\text { deficiency by GC-MS }\end{array}$ & $\begin{array}{c}\text { GAA sequencing: } \\
2 \text { heterozygous } \\
\text { (C.670>T in exon } \\
3, \mathrm{C} .1064 \mathrm{~T}>\mathrm{C} \text { in } \\
\text { exon } 6), \mathrm{HGD} \text { gene: } \\
\text { homozygous deletion } \\
\text { of } 649 \text { bp in exon } 2 \\
\text { \& surrounding DNA } \\
\text { sequences in flanking } \\
\text { introns }\end{array}$ & $\begin{array}{c}\text { Orfadin } \\
\text { (Nitisinone) }\end{array}$ \\
\hline
\end{tabular}

NA: not available; mtDNA: Mitochondrial DNA; MRCE activity: Mitochondrial respiratory chain enzyme activity; NTBC: 2(2-(2-nitro-4trifluoromethylbenzoyl)-1-3-cyclohexanedione); BH4: Tetrahydrobiopterin; PMH: Past Medical History; CPK: Creatinine Phosphokinase; GE reflux: Gastroesophageal reflux; GC-MS: Gas Chromatographic-Mass Spectrometric.

₹ Leukocyte Galactosidase A normal range: $26-80 \mathrm{nmol} / \mathrm{h} / \mathrm{mg}$.prot; N: Normal

"White Blood Cells $\alpha$-Glucosidase control level: $127 \mathrm{~nm} / \mathrm{mg}$.

Table 2: Cases of double Inborn Errors of Metabolism, their demographic, clinical, and laboratory data. 
transport sample for measuring $\alpha$-glucosidase activity ${ }^{9}$. Moreover, Jacomelli et al validated a rapid color intensity method for semi-quantification of homogentisic acid (HGA) using a dried urine spot (DUS) paper by comparing HGA concentrations in urine and plasma to those obtained from High Performance Liquid Chromatography (HPLC). The brown color intensity obtained on the paper is proportional to HGA concentration from $1.4 \mathrm{mmol} / \mathrm{L}$ to $46 \mathrm{mmol} / \mathrm{L}$. Such method fits very well for Alkaptonuria screening even before the detection of dark urine because of its safety, reliability, and ease of use ${ }^{10}$. After screening, additional confirmatory testing is necessary that include measuring enzymes activities and/or molecular analysis for gene mutations.

In our case, the patient was referred to the American University of Beirut Medical Center because of progressive motor weakness and failure to thrive at age of 6 years. His past medical history includes recurrent respiratory tract infections, greenish mucoid stools, frequent episodes of dark urine, and gastroesophageal reflux. Initial laboratory testing include a comprehensive panel for hematologic and biochemical tests in addition to urine organic acid measurements. All tests were within normal range except for creatinine phosphokinase (CPK) enzyme, plasma $\alpha$-glucosidase, homogentisic acid, and urine 1,4 $\alpha$-glucosidase. Demographic, clinical, and laboratory data are summarized in Table 2. Further molecular tests for GAA and HGD genes mutations were performed. GAA sequencing revealed a 2 heterozygous mutations, the C.670 $>\mathrm{T}$ in exon 3 , and the C.1064T>C in exon 6. HGD sequencing also revealed a homozygous deletion of 649 base pairs in exon 2 and the surrounding DNA sequences in flanking introns. The patient received orfadin (nitisinone) that improved his Alkaptonuria condition by decreasing HGA. The patient was lost to follow up since 2013 where he was waiting to receive enzyme replacement therapy (ERT).

As a conclusion, occurrence of a double genetic mutations in one person is extremely rare, specifically in our case where neither the disease prevalence, nor consanguinity are in favor to have such a rare outcome. However, it should be kept in mind there the possibility of having more than one mutation in a patient is still there, especially when the clinical presentation of the patient is complex and signs and symptoms do not fit in one disease. Presence of parental consanguinity can be an additional key point to suspect such cases. Moreover, it is of utmost importance to screen neonates and pediatric patients if clinical signs and symptoms indicate the presence of IEM as soon as possible using the dried blood neonatal cards in order to prevent the outcome of such debilitating and fatal diseases.

\section{Conflict of Interest statement}

The authors have no competing conflicts of interest in the field to disclose. This manuscript is neither submitted for publication, nor published elsewhere in the same form, in English or in any other language, without written consent of the copyright holder. The authors have contributed significantly to this paper and understand it and they all agreed to this submission. In addition, the authors have no relationship, financial or otherwise, with any manufacturers or distributors of products evaluated in this paper.

\section{References}

1. Applegarth DA, Toone JR, Lowry RB. Incidence of inborn errors of metabolism in British Columbia, 1969-1996. Pediatrics. 2000;105(1 Number):e10.

2. Hussein N, Weng SF, Kai J, Kleijnen J, Qureshi N. Preconception risk assessment for thalassaemia, sickle cell disease, cystic fibrosis and Tay-Sachs disease. The Cochrane database of systematic reviews 20158 Number):CD010849.

3. Braconi D, Millucci L, Bernardini G, Santucci A. Oxidative stress and mechanisms of ochronosis in alkaptonuria. Free radical biology \& medicine. 2015;88:70-80.

4. Millucci L, Spreafico A, Tinti L, et al. Alkaptonuria is a novel human secondary amyloidogenic disease. Biochimica et biophysica acta. 2012;1822:1682-91.

5. Dasouki M, Jawdat 0, Almadhoun 0, et al. Pompe disease: literature review and case series. Neurologic clinics 2014;32(3 Number):751-76, ix.

6. Lim JA, Li L, Raben N. Pompe disease: from pathophysiology to therapy and back again. Frontiers in aging neuroscience. 2014;6:177.

7. Selim LA, Hassan SA, Salem F, et al. Selective screening for inborn errors of metabolism by tandem mass spectrometry in Egyptian children: a 5 year report. Clinical biochemistry. 2014;47:823-8.

8. Tadmouri GO, Nair P, Obeid T, Al Ali MT, Al Khaja N, Hamamy HA. Consanguinity and reproductive health among Arabs. Reproductive health 2009;6:17.

9. Pompe Disease Diagnostic Working G, Winchester B, Bali D, et al. Methods for a prompt and reliable laboratory diagnosis of Pompe disease: report from an international consensus meeting. Molecular genetics and metabolism. 2008;93:275-81.

10. Jacomelli G, Micheli V, Bernardini G, Millucci L, Santucci A. Quick Diagnosis of Alkaptonuria by Homogentisic Acid Determination in Urine Paper Spots. JIMD reports. 2016.

11. Concolino D, Rapsomaniki M, Disabella E, et al. Co-existence of phenylketonuria and Fabry disease on a 3 year-old boy: case report. BMC pediatrics. 2010;10:32.

12. Mancuso M, Filosto M, Tsujino S, et al. Muscle glycogenosis and mitochondrial hepatopathy in an infant with mutations in both the myophosphorylase and deoxyguanosine kinase genes. Archives of neurology. 2003;60:1445-7.

13. National Organization for Rare Disorders. Angelman Syndrome. Danbury, Connecticut National Organization for Rare Disorders, 2015.

14. Ferrer-Bolufer I, Dalmau J, Quiroga R, et al. Tyrosinemia type 1 and Angelman syndrome due to paternal uniparental isodisomy 15 . Journal of inherited metabolic disease. 2009;32 Suppl 1:S349-53.

15. Illinois Department of Public Health. Tyrosinemia. Springfield, Illinois Illinois Department of Public Health, Genetics and Newborn Screening. 2016.

16. Garnica AD, Cerda JJ, Maenard D, Preiser H, Crane K. Alcaptonuria and sucrase-isomaltase deficiency in three offspring of a consanguineous marriage. Acta vitaminologica et enzymologica. 1981;3:157-69. 
17. Korten JJ. [A patient with Huntington's chorea combined with alkaptonuria and a glucose6-phosphate dehydrogenase deficiency]. Nederlands tijdschrift voor geneeskunde. 1967;111:1152-5.

18. Disorders NOfR. Huntington's Disease. Danbury, Connecticut National Organization for Rare Disorders. 2007.

19. Nicola Longo. Isobutyryl-CoA dehydrogenase deficiency. Salt Lake City, Utah Medical Home Portal, 2011.

20. Popek M, Walter M, Fernando M, Lindner M, Schwab KO, Sass JO. Two inborn errors of metabolism in a newborn: glutaric aciduria type I combined with isobutyrylglycinuria. Clinica chimica acta; international journal of clinical chemistry. 2010;411:2087-91.

21. Genetics Home Reference. glutaric acidemia type I. Rockville Pike, Bethesda, USA: National Library of Medicine. 2016.

22. Zouheir Habbal M, Bou Assi T, Mansour H. Alkaptonuria and Pompe disease in one patient: metabolic and molecular analysis. BMJ case reports. 2013.

23. Zouheir Habbal M, Bou-Assi T, Zhu J, Owen R, Chehab FF. First report of a deletion encompassing an entire exon in the homogentisate 1,2-dioxygenase gene causing alkaptonuria. PloS one. 2014;9:e106948. 